\title{
Activity of Mentha piperita L. Ethanol Extract against Acetic Acid Bacteria Asaia spp.
}

\author{
Hubert Antolak *(1), Agata Czyżowska and Dorota Kręgiel 1 \\ Institute of Fermentation Technology and Microbiology, Lodz University of Technology, Wolczanska 171/173, \\ 90-924 Lodz, Poland; agata.czyzowska@p.lodz.pl (A.C.); dorota.kregiel@p.lodz.pl (D.K.) \\ * Correspondence: hubert.antolak@gmail.com; Tel.: +48-42-6313475
}

Received: 21 September 2018; Accepted: 16 October 2018; Published: 18 October 2018

\begin{abstract}
Acetic acid bacteria belonging to the genus Asaia spp. are relatively new microbial contaminants in the beverage industry. These bacteria cause organoleptic changes such as increased turbidity, haziness and sour odor. In addition, they are able to form biofilms on the inner parts of production lines, and finally they can cause secondary contamination of final products. For this reason, new methods using effective and safe preservatives are being developed to improve microbial stability of soft beverages. The aim of the research was to investigate the effects of Mentha piperita L. ethanol extract against Asaia spp. biofilm formation. The bacterial adhesion was evaluated by a plate count method and luminometry, as well as fluorescence microscopy. The polyphenolic profile of the mint extract was determined on the basis of high-performance liquid chromatography (HPLC). The obtained microbiological results indicate bacteriostatic effect of mint extract at $10 \%(v / v)$ concentration. The plant extract also reduces the number of adhered bacterial cells on polystyrene surface.
\end{abstract}

Keywords: Asaia spp.; Mentha piperita L.; antibacterial effect; antiadhesion effect; functional beverages

\section{Introduction}

Soft drinks constitute a diverse group of products. Their classification depends on the basis of sugar or sweetener content, fruit juice and flavor addition, carbonation level, as well as their functionality. Functional beverages, except water, sweeteners, foaming agents, preservatives, aromas and colorants, contain bioactive substances such as vitamins, minerals, amino acids and proteins, dietary fiber, caffeine or taurine [1]. In addition to their basic function—body hydration—functional beverages show positive effects on consumer well-being and health. On the other hand, the addition of specific functional additives may lead to the microbial instability of final products, providing additional nutrients for spoilage microorganisms. In addition, the low $\mathrm{pH}$ level of functional drinks reaching value below 4 , along with the addition of conventional preservatives (sodium benzoate, potassium sorbate, dimethyl dicarbonate) are not usually sufficient to ensure microbial stability of final products. Soft drinks can be a favorable environment for the growth of yeasts, molds and acidophilic bacteria. Acetic acid bacteria belonging to the genera Acetobacter, Gluconobacter are often isolated from non-alcoholic drinks [2,3]. However, in recent years, functional drinks have often been contaminated by other acetic acid bacteria belonging to the genus Asaia [4-7]. Our long cooperation with Polish drinks factories shows that Asaia spp. growth occurs despite the low $\mathrm{pH}$ of the beverages and the addition of chemical preservatives [7]. As a result, manufacturers take steps aimed at preventing the appearance of defective products on the market. Therefore, our study is the consequence of cooperation with the companies interested in unknown spoilage microorganisms, which are difficult to detect and identify.

The growth of Asaia spp. in soft drinks results in formation of flocs and sediments, turbidity or color changes $[8,9]$. What is more, these bacteria show adhesion ability to various abiotic materials 
commonly used as packaging or installation pipes and accessories [10-13]. It is worth noting that biofilms formed on the inner surfaces of production lines can cause secondary contamination of final products.

Many functional drinks have been developed to provide specific medical or health benefits, such as promoting heart health, improving immunity and digestion, and helping to boost energy. Due to the trend of healthy food, the increasing interest of natural, plant-origin additives has been observed $[10,13,14]$. One of the most popular families of medicinal plants is Lamiaceae. These plants are used in traditional and modern medicine, as well as in the food industry. Representatives of this family are commonly found in Europe, Asia, North America and North Africa. The fresh and dried parts of Mentha spp., as well as their extracts, are used in aromatherapy, pharmacology and nutrition. In the food industry, the essential oils and extracts of mint are used as flavoring agents in various products, including: cheese, chocolate, soft drinks, jellies, syrups, candies and chewing gums [15]. It is worth noting that mint phytochemicals can be successfully used as natural food preservatives to prevent the growth of spoilage microorganisms [15]. The mint extracts can be used as additives to prolong the shelf-life of products, eliminating or reducing the use of synthetic preservatives and flavorings. In our work, we used ethanol extract of mint as a natural antibacterial agent against spoilage acetic acid bacteria Asaia spp. isolated from commercial soft drinks in Poland.

\section{Materials and Methods}

\subsection{Materials}

\subsubsection{Plant Extract}

Mentha piperita L. were harvested in the Lodz region (Poland) in May 2017. After harvesting, plants were washed and gently dried on paper towels and then tied in loose bunches. To protect them from dust and contamination, they were put into paper bags with small punch holes which ensured good ventilation and air circulation. Drying was carried out in a dark room at $30{ }^{\circ} \mathrm{C}$ for 30 days. Then dried leaves were crushed using a laboratory mortar and $50 \mathrm{~g}$ were then placed in $500 \mathrm{~mL}$ dark glass bottle filled with $250 \mathrm{~mL}$ of $10 \%(v / v)$ ethanol. Then bottles were stored at room temperature for one month with agitation [16]. Subsequently, the macerated leaves were centrifuged at $6500 \mathrm{rpm}$ for $10 \mathrm{~min}$. at $15{ }^{\circ} \mathrm{C}$ (Eppendorf, Hamburg, Germany). Such prepared plant extract was added to the culture media to a final concentration of $10 \%(v / v)$, while the final concentration of ethanol in a culture medium was approximately $1 \%(v / v)$. The liquid culture media with plant extracts were sterilized using microfiltration with $0.45-\mu \mathrm{m}$-pore-size membranes (Merck Millipore, Darmstadt, Germany) [16].

\subsubsection{Bacterial Strains}

Antimicrobial and antiadhesive activities of $10 \%(v / v)$ mint extract (ME) were evaluated against 6 bacterial strains of Asaia spp. characterized by strong adhesive abilities: As. bogorensis ISD1 (GenBank KP234014), As. bogorensis ISD2 (GenBank KP234015), As. bogorensis FFMW (GenBank KC756841), As. lannensis IFCW (GenBank KP234012), As. lannensis FMW1 (GenBank HQ917850), and As. lannensis W4 (GenBank MF777040). The pure cultures of bacterial strains were deposited in the Pure Culture Collection of Industrial Microorganisms LOCK 105, at the Institute of Fermentation Technology and Microbiology, Lodz University of Technology (Lodz, Poland). The bacterial strains were stored in liquid GC medium at $+4^{\circ} \mathrm{C}$. Before each experiment, strains were activated by transfer into new liquid GC media and incubation at $25^{\circ} \mathrm{C}$ for 4 days.

\subsection{Methods}

\subsubsection{Antibacterial Activity of Mint Extract}

The effect of M. piperita L. ethanol extract on the growth of Asaia spp. was investigated in liquid minimal medium $\left(2 \%(w / v)\right.$ glucose, $0.3 \%(w / v)\left(\mathrm{NH}_{4}\right)_{3} \mathrm{PO}_{4}, 0.3 \%(w / v) \mathrm{KH}_{2} \mathrm{PO}_{4}, 0.3 \%(w / v)$ 
$\mathrm{MgSO}_{4} \cdot 7 \mathrm{H}_{2} \mathrm{O}, 0.05 \%(w / v)$ yeast extract) using a modified standard method (according to EN 1040:2005) with 96 -well plates. For this purpose, $100 \mu \mathrm{L}$ of $25 \%(v / v)$ M. piperita L. ethanol extract was added to $150 \mu \mathrm{L}$ of minimal medium and mixed. Next, each microplate cell was inoculated with $50 \mu \mathrm{L}$ of the standardized bacterial suspension. The final concentration of mint extract was $10 \%(v / v)$ and concentration of bacterial cells was approximately $10^{5}-10^{6}$ cells per $\mathrm{mL}$. The control sample was inoculated minimal medium without extract. Multiplates were incubated using a MULTISKAN GO spectrophotometer (Thermo Fisher Scientific, Waltham, MA, USA) at $25^{\circ} \mathrm{C}$ for $40 \mathrm{~h}$. Measurements of absorbance were carried out automatically every $1 \mathrm{~h}$ at a wavelength of $540 \mathrm{~nm}$. The results are shown as the difference in absorbance $(\Delta \mathrm{Abs})$ after the measurement carried out for each hour $\left(\mathrm{Abs}_{\mathrm{t}}\right)$ and absorbance of medium at the beginning of the experiment $\left(\mathrm{Abs}_{0}\right)$.

\subsubsection{Bacterial Adhesion}

For adhesion studies, sterile polystyrene (PS) (Coveris Rigid Poland, Skierniewice, Poland) rectangles measuring $76 \times 26 \mathrm{~mm}$ were used. This material is certified by the Polish National Institute of Public Health and is approved for contact with food.

The adhesion and biofilm formation by bacterial strains was evaluated in liquid minimal medium $\left(2 \%(w / v)\right.$ sucrose, $0.3 \%(w / v)\left(\mathrm{NH}_{4}\right)_{3} \mathrm{PO}_{4}, 0.3 \%(w / v) \mathrm{KH}_{2} \mathrm{PO}_{4}, 0.3 \%(w / v) \mathrm{MgSO}_{4} \cdot 7 \mathrm{H}_{2} \mathrm{O}, 0.05 \%(w / v)$ yeast extract) with mint extract to obtain a final $10 \%(v / v)$ concentration. $20 \mathrm{~mL}$ of sterile medium was poured aseptically into $25 \mathrm{~mL}$ Erlenmeyer flasks covered with a textile cloth in order to ensure aerobic conditions. Sterile rectangular carriers were placed vertically into the liquid culture medium in such a way that half of the carrier was immersed in the medium. The culture media were inoculated by standardized bacterial suspension, and final concentration of bacterial cells was approximately $10^{6}$ cells per $\mathrm{mL}$ at the beginning of the experiment. The cultures were incubated at $25^{\circ} \mathrm{C}$ for 6 days on a laboratory rotary shaker at $130 \mathrm{rpm}$.

The adhesion analysis was performed by the plate count method and luminometric measurements described by Kregiel (2013) [12]. To determine the number of the bacterial cells attached to tested surfaces, the carriers were removed from the media and swabbed with a sterile contact swabs. Subsequently, the removed bacterial biofilm was placed in a saline solution with $0.1 \%(w / v)$ Tween 80 , vortexed and the appropriate dilutions were prepared. Then dilutions were transferred onto GC agar medium $\left(2 \%(w / v)\right.$ glucose, $0.3 \%(w / v)$ yeast extract, $0.3 \%(w / v)$ peptone, $0.7 \%(w / v) \mathrm{CaCO}_{3}$, $2 \%(w / v)$ agar) and incubated for $96 \mathrm{~h}$ at $25{ }^{\circ} \mathrm{C}$. After incubation, the colonies of Asaia spp. were counted and the results expressed as colony forming units per square centimeter $\left(\mathrm{CFU} / \mathrm{cm}^{2}\right)$ were determined. Additionally, the number of bacterial cells in the culture medium was evaluated, and the results expressed as colony forming units per milliliter of medium $(\mathrm{CFU} / \mathrm{mL})$. From the obtained values, the relative adhesion coefficient $A(\%)$ was calculated using the formula $A(\%)=\left(N_{a} / N_{p}\right)$ $\times 100 \%$, where $N_{a}$ is the number of attached cells to a carrier, and $N_{p}$ is the number of planktonic cells in the culture medium. For luminometric analysis, the carriers were removed from the media, washed with sterile distilled water and swabbed with pens for ATP (adenosine triphosphate) sampling. Measurements were made using a HY-LiTE ${ }^{\circledR} 2$ luminometer (Merck-Millipore, Darmstadt, Germany). The results are expressed as Relative Light Units per square centimeter $\left(\mathrm{RLU} / \mathrm{cm}^{2}\right)$ of carrier.

\subsubsection{Fluorescence Microscopy}

Visualization of bacterial cells in biofilms was performed by staining using a LIVE/DEAD ${ }^{\mathrm{TM}}$ BacLight $^{\mathrm{TM}}$ Bacterial Viability Kit (Thermo Fisher Scientific, Waltham, MA, USA) in accordance with the manufacturer's procedure. Biofilms were gently washed with phosphate buffered saline (PBS) solution, and then the entire surface was covered with a staining solution. The samples were incubated in darkness for $20 \mathrm{~min}$ at $25^{\circ} \mathrm{C}$. Images were taken using fluorescence microscope OLYMPUS BX53 equipped with filters with excitation wavelength ranging from $470 \mathrm{~nm}$ to $630 \mathrm{~nm}$, and a high-resolution digital color camera (Olympus, Tokyo, Japan) [14]. 


\subsubsection{Chemical Constituents Analysis}

The phenolic compounds contained in the tested extract were characterized using high-performance liquid chromatography (HPLC) with a diode array detector (DAD) (Finnigan Surveyor-PDA Plus detector, Thermo Fisher Scientific, Waltham, MA, USA) and ChromQuest 5.0 chromatography software (Thermo Fisher Scientific). Separation was achieved on a Lichrospher RP 18-5 ( $250 \mathrm{~mm}$ by $4.6 \mathrm{~mm}, 5 \mu \mathrm{m}$ packing; Hichrom, Reading, UK). The elution conditions were as follows: flow rate of $0.8 \mathrm{~mL} / \mathrm{min}$; oven temperature of $25^{\circ} \mathrm{C}$; solvent $\mathrm{A}(5 \%(v / v)$ formic acid), and solvent B ( $95 \%(v / v)$ acetonitrile). The injection volume was $50 \mu \mathrm{L}$. Detection was conducted at 280 , 320, and $360 \mathrm{~nm}$. The identification of compounds was carried out on the basis of the results for the standards. Gallic acid (Sigma-Aldrich, Saint Louis, MO, USA), neochlorogenic acid, chlorogenic acid (Sigma-Aldrich), epicatechin (Sigma-Aldrich), $p$-coumaric acid (Sigma-Aldrich), ferulic acid (Sigma-Aldrich), rosmarinic acid (Sigma-Aldrich), quercetin-3-rutinoside (Sigma-Aldrich), caffeic acid (Sigma-Aldrich), and quercetin (Sigma-Aldrich) were used as pure standard solutions. On the basis of results obtained for tested plant sample and pure standards, the individual components of mint extract were identified.

\subsubsection{Statistics}

Means with standard deviations were calculated from the data obtained from three independent experiments. The mean values of adhesion results were compared using one-way repeated measures analysis of variance (ANOVA; OriginPro 8.1, OriginLab Corp., Northampton, MA, USA). Values with different letters are statistically different $(p<0.05)$. $a-p \geq 0.05 ; b-0.005<p<0.05 ; c-p<0.005$. The results were compared with data received for the control culture medium (without mint extract). Bacterial growth profiles were created in Plotly (https://plot.ly/\#/)—a free web tool for data visualization.

\section{Results and Discussion}

\subsection{Antibacterial Activity}

The biological activities of mint extract were evaluated against six strains of Asaia spp. under in vitro conditions. The tested ethanol extract showed weak bacteriostatic properties (Figure 1). The maximum value of absorbance after $40 \mathrm{~h}$ of cultivation in the control medium (minimal medium) was approximately 0.28 . The best growth was obtained for As. bogorensis ISD2, while among As. lannensis, strain IFCW showed the best proliferation. However, in the medium containing $10 \%$ $(v / v)$ extract of M. piperita L., bacterial growth was slightly inhibited, and the maximum value of absorbance was approximately 0.21 . Antibacterial activity of mint extracts against Gram-positive and Gram-negative bacteria is well documented. Sujana et al., (2013) found that M. piperita L. leaf extract showed stronger activity against Gram-positive Staphylococcus aureus (Staph. aureus), Bacillus subtilis (B. subtilis) than against Gram-negative Escherichia coli (E. coli) [17]. Antibacterial effect of peppermint water extract was also noted against Pseudomonas aeruginosa (Ps. aeruginosa) and Serratia marcescens [18]. The studies conducted by Laggoune et al., (2016) indicated that E. coli and Proteus mirabilis strains were sensitive to Mentha spicata (M. spicata) [19]. What is more, in the study of Dhiman et al. (2016), the authors tested the effect of acetone, methanol, ethanol, and water extracts of mint against spoiled juice-isolated microorganisms: Bacillus cereus and Serratia spp. [20]. Despite the fact that in the in vivo studies, the extract of mint showed a bacteriostatic effect, it should be remembered that this activity can be clearly different in a food industry environment. In general, biological activity can be influenced by food components (e.g., fats, carbohydrates, proteins, water, salt, preservatives), temperature, $\mathrm{pH}$, water activity and packaging methods. Thus, to confirm the effectiveness of improving the stability and shelf-life of products through the growth inhibition of Asaia spp., it is necessary to conduct tests using the appropriate matrix. 




Figure 1. The growth of As. bogorensis (ISD1, ISD2, FFMW) and As. lannensis (IFCW, FMW1, W4) in the control culture medium and the medium with mint extract.

\subsection{Antiadhesive Activity}

Analysis of Asaia spp. adhesion to polystyrene surfaces was carried out in minimal medium with $10 \%(v / v)$ mint extract. The results of the plate count method and luminometry, expressed respectively as adhesion coefficient A (\%) and adhesion $\left(\mathrm{RLU} / \mathrm{cm}^{2}\right)$, are presented in Figure 2. Both methods showed that Asaia spp. strains are characterized by strong adhesion properties. The relative coefficient A (\%) for minimal medium ranged from $0.47 \%$ for As. lannensis IFCW to $1.11 \%$ for As. lannensis ISD2. The results of luminometry showed that adhesion ranged from $4430 \mathrm{RLU} / \mathrm{cm}^{2}$ for As. lannensis IFCW to $8450 \mathrm{RLU} / \mathrm{cm}^{2}$ for As. bogorensis W4. The results agree with those obtained by Kregiel and co-workers [11,12]. Our research confirmed that adhesion is a strain-dependent feature. According to the literature, adhesion of bacterial cells to different surfaces is usually correlated with the cell starvation. Biofilm formation occurs in rather poor environments, and in the case of Asaia spp., in the presence of sucrose as a carbon source. The knowledge of factors involved in biofilm formation by Asaia spp. is limited, but it has been shown that extracellular polymeric substances promote biofouling [12]. The physicochemical properties of abiotic materials play an important role in this phenomenon. It is known that adhesion to hydrophobic surfaces happens more intensively in comparison to hydrophilic surfaces with lower contact angles. Plastic materials, such as polystyrene, with a higher contact angle $\left(87^{\circ}\right)$ and low free energy $\left(40 \mathrm{mN} / \mathrm{m}\right.$ at $20^{\circ} \mathrm{C}$ ), are more hydrophobic than glass (contact angle $44^{\circ}$ and surface free energy equal $70 \mathrm{mN} / \mathrm{m}$ at $20^{\circ}$ ). Thus, we may conclude that plastic packaging materials commonly used in beverage industry support bacterial adhesion and biofilm formation [21]. Therefore, novel effective antibiofilm strategies are urgently needed.

A great number of studies on antibiofilm strategies are focused on surface modification, and many approaches are based on active organosilanes [22-24] or nanostructured antibacterial multilayers $[25,26]$. Also, hygienic processes with the application of novel surfactants, stimulating biofilm eradication, have been used $[27,28]$. However, taking into account the dynamic development of the healthy food trend and the impact on the health and well-being of consumers, a modification of soft drink contents seems much more justified. An interesting alternative may be the addition of natural plant extracts and juices as a source of bioactive compounds to prevent microbial growth and adhesion.

The application of mint extract caused the reduction in cells adhesion of almost all Asaia spp. strains. The values of the relative adhesion coefficient A (\%) show that $10 \%(v / v)$ mint extract inhibited adhesion of all strains of As. bogorensis and As. lannensis (Figure 2A). However, the reduction of coefficient A (\%) for As. bogorensis FFMW and As. lannensis W4 was not statistically significant compared to the control medium $(p \geq 0.05)$. The highest decrease of $\mathrm{A}(\%)$ values $(73 \%)$, between adhesion in the medium with mint extract and adhesion in control medium, was noted for As. bogorensis ISD1. A slight decrease in the relative adhesion coefficient A (\%) was noted for As. bogorensis FFMW and As. lannensis W4. On the other hand, the results obtained by the luminometric method were more divergent. According to the values of relative light units per square centimeter of the carrier 
[RLU $\left./ \mathrm{cm}^{2}\right]$, the antiadhesive effect of mint extract was significant for most of tested strains. Only for two strains-As. bogorensis FFMW and As. lannensis W4-was a slight increase in adhesion noted. However, these results were not statistically significant $(p \geq 0.05)$. The strongest antiadhesive activity was noted for As. bogorensis ISD1 and As. lannensis FMW1. For ISD1, the luminometric values were reduced from the $7320 \mathrm{RLU} / \mathrm{cm}^{2}$ to $4100 \mathrm{RLU} / \mathrm{cm}^{2}$ (decrease by $44 \%$ ). Meanwhile, for FMW1, a reduction from $4450 \mathrm{RLU} / \mathrm{cm}^{2}$ to $2450 \mathrm{RLU} / \mathrm{cm}^{2}$ was noted.

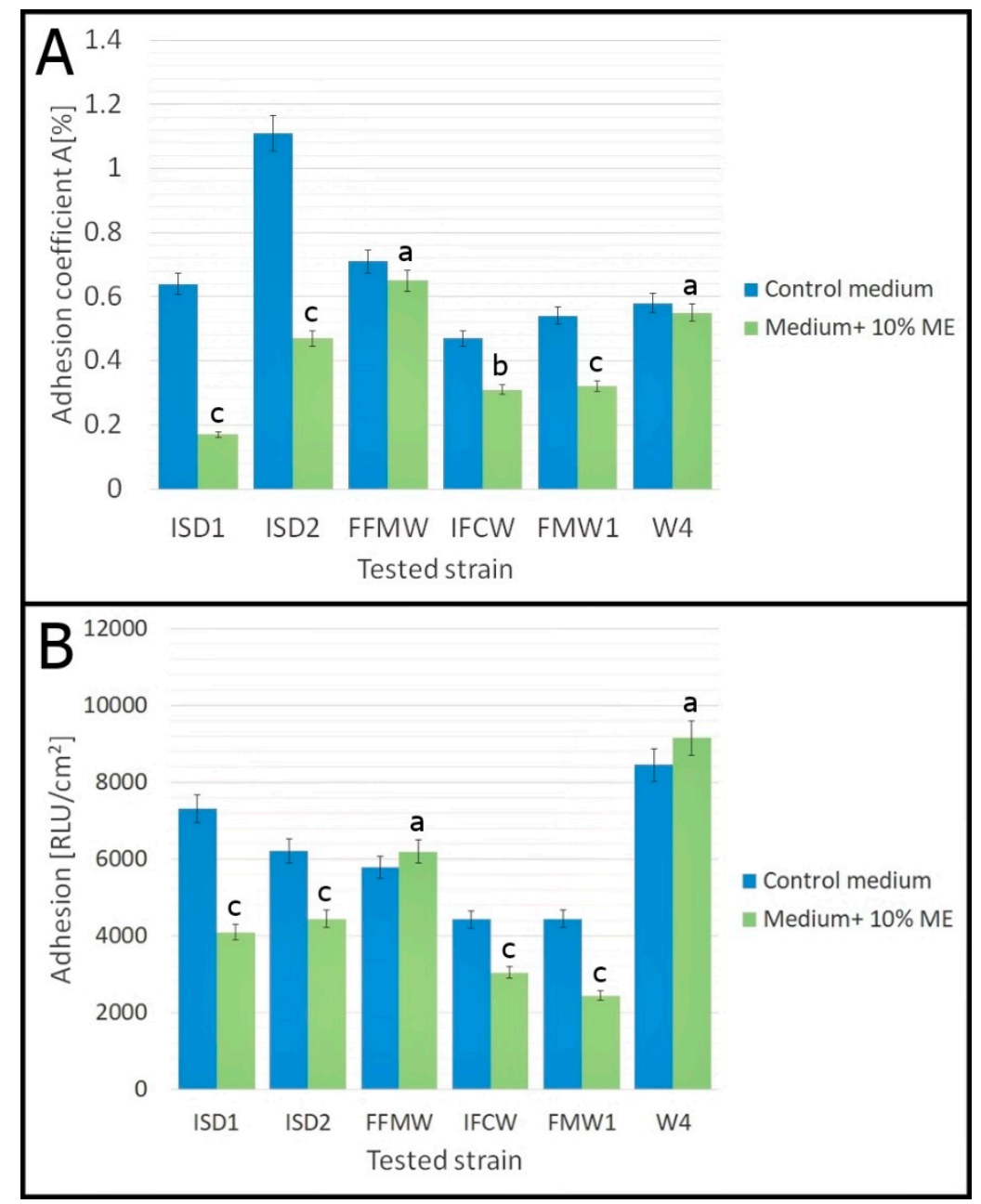

Figure 2. The effect of $10 \%(v / v)$ M. piperita L. mint extract (ME) on the adhesion of As. bogorensis (ISD1, ISD2, FFMW) and As. lannensis (IFCW, FMW1, W4). (A) Results of the plate count method. (B) Results of the luminometric method. Results obtained for control samples (without mint extract) were compared with results for samples with $10 \%(v / v)$ mint extract using one-way repeated measures analysis of variance (ANOVA). The values with different letters are statistically different $(p<0.05)$. $a-p \geq 0.05 ; b-0.005<p<0.05 ; c-p<0.005$. The results were compared with data received for the control medium.

According to Figure 3, there are two potential mechanisms of inhibition of biofilm formation by mint extract. First of all, it may show antibacterial activity, which is evidenced by spectrophotometric results and fluorescence microscopic images. Figure 3B,D show biofilm formed after 3-day and 6-day incubation of As. bogorensis ISD2 in the medium with 10\% $(v / v)$ ME. In both cases, a significant proportion of dead (red) cells to live (green) was visible. What is more, in comparison to biofilms in the control sample (without mint extract), Figure 3A,C show a lower level of living cells. The bacterial viability kit used in our study was a mixture of $\mathrm{SYTO}^{\circledR} 9$ (green-fluorescent nucleic acid) stain and propidium iodide (red-fluorescent) stain. $\mathrm{SYTO}^{\circledR} 9$ used alone labels both bacteria with damaged 
membranes and those with intact membranes. In turn, propidium iodide exhibits activity only in relation to bacteria with damaged membranes, and at the same time, it causes $\mathrm{SYTO}^{\circledR} 9$ reduction. As a consequence, undamaged cells show green fluorescence while cells with damaged membranes are red [14]. On the other hand, the second mechanism may rely on direct anti-adhesion activities against Asaia spp. cells. By comparing the surfaces of biofilms, meaningfully smaller areas of biofilms were formed in the medium with the addition of the mint extract than in the case of in the control media. Literature data on antiadhesive and antibiofilm activities of mint extracts is limited. A few previous reports have shown that essential oils and extracts prepared from M. piperita inhibited biofilm formation by bacteria Listeria monocytogenes, Pseudomonas aeruginosa, as well as yeasts belonging to Candida species [29].

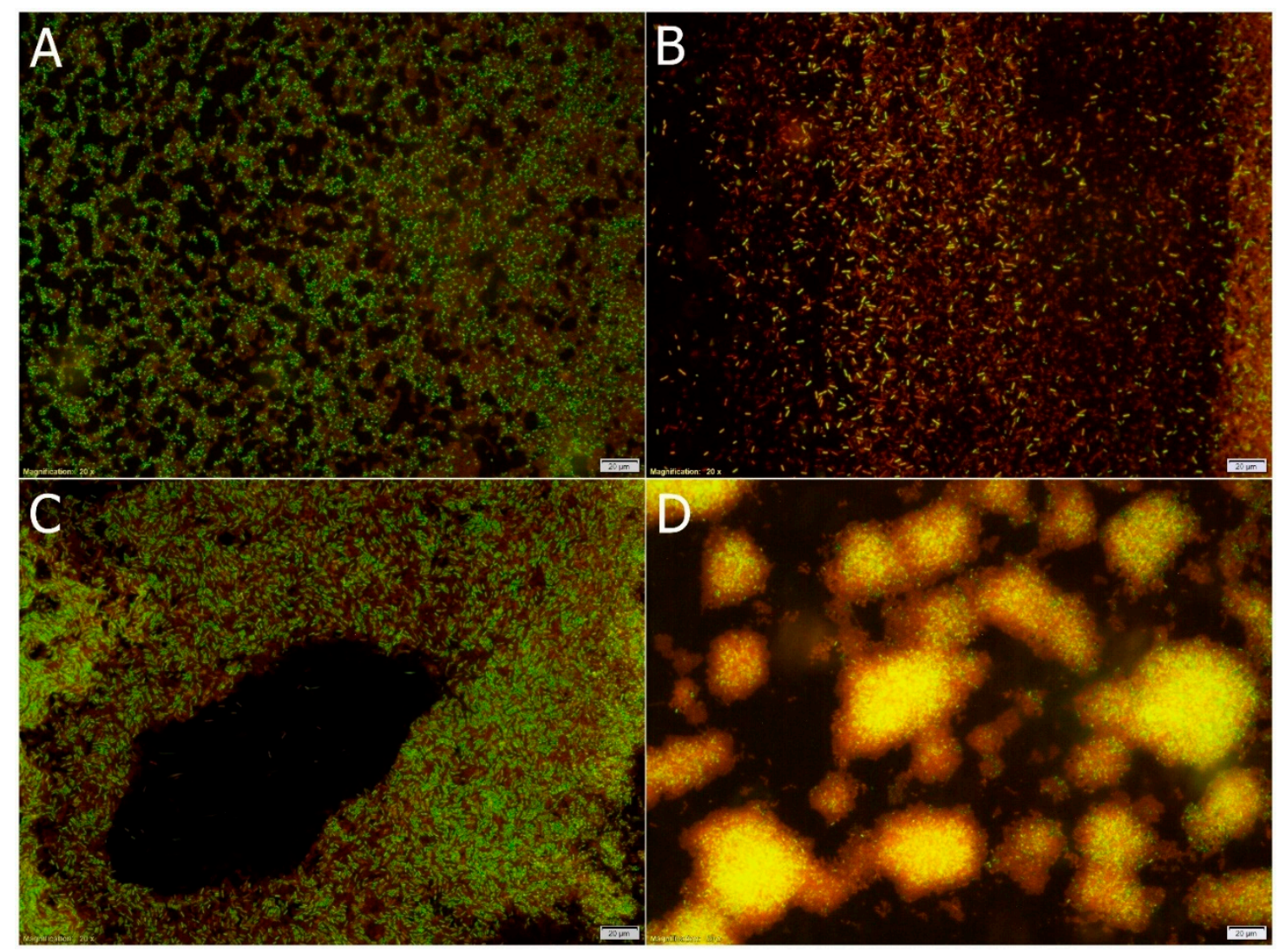

Figure 3. Microscopic observation of As. bogorensis ISD2 biofilms formed after 3-days-incubation (A,B) and 6-days-incubation $(\mathbf{C}, \mathbf{D})$ in minimal medium $(\mathbf{A}, \mathbf{C})$ and medium with $10 \%(v / v)$ M. piperita L. (B,D).

\subsection{Chemical Composition}

Plants of the genus Mentha show a great chemical variability. Reports on chemical composition of mint species showed that many factors interfere with bioactive compound composition, among them environmental (growth location, soil characteristics, moisture presence, temperature, etc.), phenological (phase of the plant collection), plant part used for extraction (flowers, stems, leaves, entire aerial parts or inflorescences), type of material (fresh or dry), and even methods used for chemical analysis. According to the literature, rosmarinic acid, luteolin-7-O-glucoside, salvianolic acid, eriocitrin and hesperidin have been found as the major non-volatile constituents in Mentha species [15]. As can be seen in Table 1, the mint extract used in the study was a source mainly of phenolic acids, such as gallic, chlorogenic, neochlorogenic, p-coumaric, ferulic as well as rosmarinic acids. In addition, the presence of epicatechin, quercetin-3-rutinoside and quercetin was also found. 
Table 1. Main phenolic compounds in mint extract identified by HPLC.

\begin{tabular}{cccc}
\hline No. & Time & $\lambda_{\max }(\mathbf{n m})$ & Proposed Molecule \\
\hline 1 & 3.783 & 277 & Gallic acid \\
2 & 11.073 & 324 & Neochlorogenic acid \\
3 & 16.323 & 323 & Chlorogenic acid \\
4 & 17.415 & 279 & Epicatechin \\
5 & 20.868 & 308 & p-Coumaric acid \\
6 & 23.787 & 322 & Ferulic acid \\
7 & 30.947 & 290 & Rosmarinic acid \\
8 & 32.133 & 318 & Quercetin-3-rutinoside \\
9 & 33.993 & 322 & Caffeic acid derivative \\
10 & 54.065 & 318 & Quercetin \\
\hline \multicolumn{4}{c}{}
\end{tabular}

The phenolic acid content, as well as the essential oils, in the mint extracts has an influence on the biological activities of this plant material. It has been documented that gallic and caffeic acids show activity against the Gram-negative Klebsiella pneumoniae and Gram-positive Staphylococcus epidermidis, as well as Staph. aureus [30]. It is well known that, along with phenolic acids, mint is a rich source of essential oils (EOs). It is believed that antimicrobial activity of the extract is the result of the synergistic actions of various bioactive compounds contained in the tested extract [18]. Dhifi et al., (2013) reported that Mentha spicata essential oil showed high activity against Gram-positive bacteria Staph. epidermidis and Staph. aureus, as well as Gram-negative cells of Salmonella spp. and E. coli [31]. Soković et al., (2010) found that M. piperita and M. spicata essential oils were more active than oils from sweet basil, lavender, sage or camomile against a wide spectrum of bacterial strains: B. subtilis, E. coli O157:H7, Ps. aeruginosa, Proteus mirabilis, Salmonella spp. and Staph. aureus [32]. They also noted that menthol was more active than other compounds extracted from tested plants: linalyl acetate, limonene, $\beta$-pinene, $\alpha$-pinene, camphor, linalool and 1,8-cineole. In general, the better activity of both the extracts and essential oils of mint have been noted for Gram-positive bacteria. Presumably, the lower susceptibility of Gram-negative bacteria results inter alia from the presence of hydrophobic lipopolysaccharides in their outer membrane, which provides protection against different antimicrobial agents [33]. This structure prevents the depolarization, pores formation and increasing of membrane permeability [34]. The crucial factors affecting the antimicrobial activity include: the composition of used extract, the concentration of active substances as well as the type of tested microorganism. The composition of active substances may be determined by plant cultivation method, environmental conditions, time of plant harvesting, method of plant drying, and storage conditions, as well as extraction method [35].

\section{Conclusions}

The ethanol extract of Mentha piperita L. shows bacteriostatic properties and antiadhesive activity against Asaia spp. strains isolated from commercial soft drinks. Our study results suggested that Mentha piperita L. extract can be considered as a good source of natural compounds with significant antioxidant activity. The antiadhesive action of mint makes it an interesting component of soft drinks to counteract the formation of bacterial cell aggregates, flocks, haziness, biofilms and, finally, it will allow to find several applications for shelf-life extending of soft drinks.

Author Contributions: H.A. conceived and designed the experiments; H.A. and A.C. performed the analysis on HPLC; H.A. performed the microbiological analysis; H.A. and D.K. wrote the article.

Funding: This research was funded by National Science Centre, Poland grant number 2015/17/N/NZ9/0363.

Conflicts of Interest: The authors declare no conflict of interest. 


\section{References}

1. Kregiel, D. Health safety of soft drinks: Contents, containers, and microorganisms. Biomed. Res. Int. 2015, 2015, 128697. [CrossRef] [PubMed]

2. Walker, M.; Phillips, C.A. The effect of preservatives on Alicyclobacillus acidoterrestris and Propionibacterium cyclohexanicum in fruit juice. Food Control 2008, 19, 974-981. [CrossRef]

3. Sokołowska, B.; Skąska, S.; Fonberg-Broczek, M.; Niezgoda, J.; Chotkiewicz, M.; Dekowska, A.; Rzoska, S.J. Factors influencing the inactivation of Alicyclobacillus acidoterrestris spores exposed to high hydrostatic pressure in apple juice. High Press. Res. 2013, 33, 73-82. [CrossRef]

4. Moore, J.E.; McCalmont, M.; Xu, J.; Millar, B.C.; Heaney, N. Asaia sp., an unusual spoilage organism of fruit-flavored bottled water. Appl. Environ. Microbiol. 2002, 68, 4130-4131. [CrossRef] [PubMed]

5. Sedláčková, P.; Čeřovský, M.; Horsáková, I.; Voldřich, M. Cell surface characteristic of Asaia bogorensisspoilage microorganism of bottled water. Czech J. Food Sci. 2011, 29, 457-461. [CrossRef]

6. Horsáková, I.; Voldřich, M.; Čeřovskỳ, M.; Sedláčková, P.; Šicenrová, P.; Ulbri, P. Asaia sp. as a bacterium decaying the packaged still fruit beverages. Czech J. Food Sci. 2009, 27, 362-365. [CrossRef]

7. Kregiel, D.; James, S.A.; Rygała, A.; Berłowska, J.; Antolak, H.; Pawlikowska, E. Consortia formed by yeasts and acetic acid bacteria Asaia spp. in soft drinks. Antonie Leeuwenhoek 2018, 11, 373-383. [CrossRef] [PubMed]

8. Kręgiel, D.; Rygała, A.; Libudzisz, Z.; Walczak, P.; Ołtuszak-Walczak, E. Asaia lannensis-The spoilage acetic acid bacteria isolated from strawberry-flavored bottled water in Poland. Food Control 2012, 26, 147-150. [CrossRef]

9. Antolak, H.; Oracz, J.; Otlewska, A.; Żyżelewicz, D.; Kręgiel, D. Identification of carotenoids and isoprenoid quinones from Asaia lannensis and Asaia bogorensis. Molecules 2017, 22, 1608. [CrossRef] [PubMed]

10. Antolak, H.; Czyżowska, A.; Kręgiel, D. Black currant (Ribes nigrum L.) and bilberry (Vaccinium myrtillus L.) fruit juices inhibit adhesion of Asaia spp. Biomed. Res. Int. 2016, 2016, 3671306. [CrossRef] [PubMed]

11. Kręgiel, D.; Otlewska, A.; Antolak, H. Attachment of Asaia bogorensis originating in fruit-flavored water to packaging materials. Biomed. Res. Int. 2014, 2014, 514190. [CrossRef] [PubMed]

12. Kregiel, D. Attachment of Asaia lannensis to materials commonly used in beverage industry. Food Control 2013, 32, 537-542. [CrossRef]

13. Antolak, H.; Kręgiel, D.; Czyżowska, A. Adhesion of Asaia bogorensis to glass and polystyrene in the presence of cranberry juice. J. Food Prot. 2015, 78, 1186-1190. [CrossRef] [PubMed]

14. Antolak, H.; Czyżowska, A.; Sakač, M.; Mišan, A.; Đuragić, O.; Kręgiel, D. Phenolic compounds contained in little-known wild fruits as antiadhesive agents against the beverage-spoiling bacteria Asaia spp. Molecules 2017, 22, 1256. [CrossRef] [PubMed]

15. Salehi, B.; Stojanović-Radić, Z.; Matejić, J.; Sharopov, F.; Antolak, H.; Kręgiel, D.; Sen, S.; Sharifi-Rad, M.; Acharya, K.; Sharifi-Rad, R.; et al. Plants of genus Mentha: From farm to food factory. Plants 2018, 7, 70. [CrossRef] [PubMed]

16. Antolak, H.; Czyżowska, A.; Kręgiel, D. Antibacterial and antiadhesive activities of extracts from edible plants against soft drink spoilage by Asaia spp. J. Food Prot. 2017, 80, 25-34. [CrossRef] [PubMed]

17. Sujana, P.; Sridhar, T.M.; Josthna, P.; Naidu, C.V. Antibacterial activity and phytochemical analysis of Mentha piperita L. (peppermint)—An important multipurpose medicinal plant. Am. J. Plant Sci. 2013, 4, 77-83. [CrossRef]

18. Bupesh, G.; Amutha, C.; Nandagopal, S.; Ganeshkumar, A.; Sureshkumar, P.; Murali, K.S. Antibacterial activity of Mentha piperita L. (peppermint) from leaf extracts-A medicinal plant. Acta Agric. Slov. 2007, 89, 73-79. [CrossRef]

19. Laggoune, S.; Öztürk, M.; Erol, E.; Duru, M.E.; Abaza, I.; Kabouche, A.; Kabouche, Z. Chemical composition, antioxidant and antibacterial activities of the essential oil of Mentha spicata L. from Algeria. J. Mater. Environ. Sci. 2016, 7, 4205-4213.

20. Dhiman, R.; Aggarwal, N.; Aneja, K.R.; Kaur, M. In vitro antimicrobial activity of spices and medicinal herbs against selected microbes associated with juices. Int. J. Microbiol. 2016, 9015802. [CrossRef]

21. Liu, Y.; Zhao, Q. Influence of surface energy of modified surfaces on bacterial adhesion. Biophys. Chem. 2005, 117, 39-45. [CrossRef] [PubMed]

22. Kreggiel, D. Advances in biofilm control for food and beverage industry using organo-silane technology: A review. Food Control 2014, 40, 32-40. [CrossRef] 
23. Kregiel, D.; Niedzielska, K. Effect of plasma processing and organosilane modifications of polyethylene on Aeromonas hydrophila biofilm formation. Biomed. Res. Int. 2014, 2014, 232514. [CrossRef] [PubMed]

24. Kręgiel, D.; Berłowska, J.; Mizerska, U.; Fortuniak, W.; Chojnowski, W.; Ambroziak, W. Chemical modification of polyvinyl chloride and silicone elastomer in inhibiting adhesion of Aeromonas hydrophila. World J. Microbiol. Biotechnol. 2013, 29, 1197. [CrossRef] [PubMed]

25. Kruk, T.; Szczepanowicz, K.; Kręgiel, D.; Szyk-Warszyńska, L.; Warszyński, P. Nanostructured multilayer polyelectrolyte films with silver nanoparticles as antibacterial coatings. Colloids Surf. B. Biointerfaces 2016, 137, 158-166. [CrossRef] [PubMed]

26. Marcous, A.; Rasouli, S.; Ardestani, F. Low-density polyethylene films loaded by titanium dioxide and zinc oxide nanoparticles as a new active packaging system against Escherichia coli O157:H7 in fresh calf minced meat. Packag. Technol. Sci. 2017. [CrossRef]

27. Antolak, H.; Mizerska, U.; Berłowska, J.; Otlewska, A.; Kregiel, D. Quillaja saponaria saponins with potential to enhance the effectiveness of disinfection processes in the beverage industry. Appl. Sci. 2018, 8, 368. [CrossRef]

28. Koziróg, A.; Kręgiel, D.; Brycki, B. Action of monomeric/gemini surfactants on free cells and biofilm of Asaia lannensis. Molecules 2017, 22, 2036. [CrossRef] [PubMed]

29. De Feiria, S.N.B.; de Laet Santana, P.; Boni, G.C.; Anibal, P.C.; Boriollo, M.F.G.; Figueira, G.M.; de Oliveira Sousa, I.M.; Pereira, B.; Foglio, M.A.; Höfling, J.F. Essential oil composition of Mentha spp. extracted seasonally and their effects against Candida yeast growth and biofilm formation. Adv. Med. Plant. Res. 2016, 4, 106-129.

30. Perumalla, A.V.S.; Hettiarachchy, N.S. Green tea and grape seed extracts-Potential applications in food safety and quality. Food Res. Int. 2011, 44, 827-839. [CrossRef]

31. Dhifi, W.; Jelali, N.; Mnif, W.; Litaiem, M.; Hamdi, N. Chemical composition of the essential oil of Mentha spicata L. from Tunisia and its biological activities. J. Food Biochem. 2013, 37, 362-368. [CrossRef]

32. Soković, M.D.; Glamočlija, J.; Marin, P.D.; Brkić, D.; van Griensven, L.J.L.D. Antibacterial effects of the essential oils of commonly consumed medicinal herbs using an in vitro model. Molecules 2010, 15, 7532-7546. [CrossRef] [PubMed]

33. Shahbazi, Y. Chemical composition and in vitro antibacterial activity of Mentha spicata essential oil against common food-borne pathogenic bacteria. J. Pathog. 2015. [CrossRef] [PubMed]

34. Hyldgaard, M.; Mygind, T.; Meyer, R.L. Essential oils in food preservation: Mode of action, synergies, and interactions with food matrix components. Front. Microbiol. 2012. [CrossRef] [PubMed]

35. Roidaki, A.; Zoumpoulakis, P.G.; Proestos, C. Comparison of extraction methods for the determination of antioxidant activity in extracts of Hippophae rhamnoides L. and Lippia citriodora. The effect of seasonal collection. Austin J. Nutr. Food Sci. 2015, 3, 1057-1064. 